Check for updates

Montreal

Cite this as: $B M J 2021 ; 375: \mathrm{n} 2781$ http://dx.doi.org/10.1136/bmj.n2781 Published: 12 November 2021

\title{
Covid-19: Moderna seeks to exclude US government scientists from vaccine patents, despite public investment
}

\section{Owen Dyer}

A behind-the-scenes struggle between the drug company Moderna and the US government over the intellectual property rights of the company's coronavirus vaccine seems to be heading to court, in a case that could be pivotal to the effort to bring vaccines to less wealthy countries.

The US National Institutes of Health has been trying to resolve the situation amicably for nearly a year without success, NIH director Francis Collins told Reuters. "But we are not done," he said. "Clearly this is something that legal authorities are going to have to figure out." 1

The NIH gave Moderna $\$ 1.4 \mathrm{bn}$ to develop the vaccine and lent the company its scientists and facilities. Announcing its application for emergency authorisation last year, the current US chief medical adviser, Anthony Fauci, called it the "NIH-Moderna covid-19 vaccine."

The agency credits three scientists at its vaccine research centre with central roles in its invention: John Mascola, the centre's director; Barney Graham, who recently retired; and Kizzmekia Corbett, who has since moved to Harvard. They helped to design the key genetic sequence that prompts the vaccine to produce an immune response, and they should be named on the "principal patent application," the NIH contends. Corbett, whose team first stabilised a viral spike protein in an mRNA vaccine, has been hailed as a role model for black women in science.

But this week the US watchdog group Public Citizen revealed that in a July patent application Moderna, referring to the three government scientists, wrote that the company had "reached the good-faith determination that these individuals did not co-invent" the sequence. The company's filing names only Moderna scientists.

Public Citizen wrote to the NIH's Collins urging him to "ensure the contributions of federal scientists are fully recognised."

After Collins predicted legal action, Peter Maybarduk, director of Public Citizen's Access to Medicines programme, congratulated the government for "showing a modicum of verve at last, suggesting it will not allow federal scientists' role in the invention of the NIH-Moderna vaccine to be erased." He added, "Moderna has turned this people's vaccine into a rich people's vaccine; refusing to share technology with WHO or developing country manufacturers and sharing very few doses with COVAX while overcharging poor nations."

Co-ownership of the patent would enable the US government to license manufacturers abroad. The Biden administration has been critical of Moderna's reluctance to build production capacity in developing nations. Moderna's share price has fallen by $30 \%$ in the past 10 days after it downgraded production estimates for the next year.

Both Moderna and the NIH issued statements confirming their ongoing dispute. Moderna spokeswoman Colleen Hussey said the company has "all along recognised the substantial role that the NIH has played in developing Moderna's covid-19 vaccine" but is legally bound to exclude the agency from the patent application, because “only Moderna's scientists designed" the sequence. ${ }^{3}$

Collins said that a dispute that had been kept under wraps could become more contentious now that it was public knowledge. "I think Moderna has made a serious mistake here in not providing the kind of co-inventorship credit to people who played a major role in the development of the vaccine that they're now making a fair amount of money off of," he told Reuters.

"I did not expect that to be the outcome from what had been a very friendly, collaborative effort between scientists at NIH and Moderna over many years. It's not a good idea to file a patent when you leave out important inventors, and so this is going to get sorted as people look harder at this.”

\section{Steenhuysen J. Moderna covid-19 vaccine patent dispute headed to court, US NIH head says. Nov 2021. https://www.reuters.com/business/healthcare- pharmaceuticals/moderna-covid-19-vaccine-patent-dispute-headed-court- us-nih-head-says-2021-11-10. \\ 2 Read Public Citizen's letter on the Moderna vaccine patent dispute. New York Times 9 Nov 2021. https://www.nytimes.com/interac- tive/2021/11/09/us/public-citizen-nih-moderna-vaccine.html. \\ 3 Moderna. Statement on intellectual property. 11 Nov 2021. https://in- vestors.modernatx.com/news-releases/news-release-details/statement- intellectual-property.}

This article is made freely available for use in accordance with BMJ's website terms and conditions for the duration of the covid-19 pandemic or until otherwise determined by BMJ. You may use, download and print the article for any lawful, non-commercial purpose (including text and data mining) provided that all copyright notices and trade marks are retained. 